\title{
Anticancer and antioxidant activities of Cordia dichotoma Forst
}

\section{Nazim Hussain', Bibhuti Bhushan Kakoti', Mithun Rudrapal', Julfikar Ali Junejo', Moksood Ahmed Laskar' ${ }^{2}$, Makhan Lal ${ }^{3}$, Khomendra Kumar Sarwa ${ }^{4}$}

${ }^{1}$ Department of Pharmaceutical Sciences, Dibrugarh University, Dibrugarh, Assam, India, ${ }^{2}$ Department of Pharmacology, Faculty of Pharmaceutical Sciences, Assam Downtown University, Guwahati, Assam, India, ${ }^{3}$ Department of Pharmaceutical Sciences, Lovely Professional University, Phagwara, Jalandhar, Punjab, India, ${ }^{4}$ Department of Pharmacy, Government Girls Polytechnic, Raipur, Chhattisgarh, India

\begin{abstract}
Objective: The present study was carried out to evaluate the antitumor and antioxidant activities of the methanol extract of Cordia dichotoma (MECD) against EAC in Swiss albino mice. Materials and Methods: The present study evaluated the anticancer effect of the methanolic extract of $C$. dichotoma (MECD) bark against Ehrlich ascites carcinoma (EAC) cells induced in albino mice and against human cancer cell lines (malondialdehyde-MB-231 and MCF-7 cells). Results and Discussion: There was significant fall in the red blood cell count and hemoglobin $(\mathrm{Hb})$ content, and a significant increase in white blood cell (WBC) count in the EAC control mice as compared to normal control mice. Treatment with MECD (500 mg/kg, b.w., p.o.) or 5-Fluorouracil ( $20 \mathrm{mg} / \mathrm{kg}$ b.w., i.p.) in EAC-cell bearing mice caused a significant $(P<0.01)$ increase in Hb levels while a significant $(P<0.01)$ decrease in WBC levels compared to EAC control rats. Furthermore, increase in the concentration of MECD dosedependently increased the percent cytotoxicity and decreased the cell viability in both cell line types. The results with MECD were comparable to the tamoxifen. The maximum gain of body weight was observed in the EAC control group. In case of MECD and 5-Fluorouracil treated groups, the body weight was significantly $(P<0.01)$ reduced. The tumor volume and tumor weight were found to be significantly $(P<0.05$ or $P<0.01)$ decreased in MECD treated animals at the doses 250 and $500 \mathrm{mg} / \mathrm{kg}$ and 5-Fluorouracil $(20 \mathrm{mg} / \mathrm{kg})$ when compared with EAC control animals. With MECD treatment, the survival of EAC bearing mice significantly $(P<0.01)$ increased as compared to EAC bearing control group. In treated group, mean survival time (MST) was significantly increased to $29.0 \pm 1.98(\% \mathrm{ILS}=69.04), 34.12 \pm 1.84(\% \mathrm{ILS}=81.25)$, and $36.87 \pm 1.67(\% \mathrm{ILS}=87.79)$, respectively, when compared to EAC control group. Conclusion: The results of the current study propose that the antitumor activity of MECD can be inferred from the increased life span of EAC bearing mice which is due to its antioxidant activity.
\end{abstract}

Key words: Anticancer, antioxidant, carcinoma, Cordia dichotoma, flavonoid

\section{INTRODUCTION}

$\mathrm{M}$ alignant neoplasm is a major health concern in which a group of cells shows abnormal proliferation, invasion, and sometimes metastasis..$^{[1]}$ Current estimate projects that, in 2015, there were 8.8 million cancer deaths across the globe, ${ }^{[2]}$ with an estimated 19.3 million new cases per year by $2025 .{ }^{[3]}$ Chemotherapy is a major challenge for the cancer patients because of its potent and toxicity. The need for new drugs required due to the increased body resistance to the available chemotherapeutic agents. ${ }^{[4]}$ Numerous efforts have been made to search for new anticancer therapeutic approaches. One such effort is investigation of plant products for their anticancer effects. Plants have a long history of use in cancer treatment. ${ }^{[5]}$ Scientific research on plants has led to the discovery of many drugs in the past including anticancer drugs. ${ }^{[6]}$ Experimental tumors such as Ehrlich ascites carcinoma (EAC) have pronounced significance for the purposes of modeling. The characteristics features of EAC includes poor differentiation, originally hyperdiploid, highly transplantable, $100 \%$ malignancy, no-regression, rapid proliferation, shorter life span, and with no tumor specific transplantation antigen. EAC has been used as

Address for correspondence: Nazim Hussain,

Department of Pharmaceutical Sciences, Dibrugarh

University, Dibrugarh, Assam, India.

E-mail: nhussain116@gmail.com

Received: $13-05-2020$

Revised: 29-06-2020

Accepted: 09-07-2020 
a transplantable murine tumor model in ascitic form to evaluate the antitumor effects of several drugs. ${ }^{[4-6]}$

Cordia dichotoma (Family: Boraginaceae) is one of the traditional medicinally important deciduous plants available all over India. Ripe fruit of $C$. dichotoma plant is used as antibacterial, antiviral, and antitussive. Leaves and stem bark are used in the treatment of fever, diarrhea, dyspepsia, leprosy, and gonorrhea. Leafs are used traditionally as astringent, anthelmintic, diuretic, purgative, expectorant, demulcent, tonic, and ulcer. Various experts have documented the aforementioned properties on other plants and their parts of Boraginaceae family except for C. dichotoma Forst. Bark. ${ }^{[7-11]}$ However, there is no logical proof of study on the bark of the $C$. dichotoma Forst.

Despite the fact that the whole plant has antileprotic and antidiabetic activity ${ }^{[8]}$ The genus, Cordia has been documented for having other properties such as anthelmintic, wound healing, anti-inflammatory, antiulcer, gastro-protective, and antioxidant. ${ }^{[12-14]}$ Various experts have documented the aforementioned properties on other plants and their parts of Boraginaceae family except for $C$. dichotoma Forst. Bark. However, there is no logical proof of study on the bark of the $C$. dichotoma Forst. plant of the Boraginaceae family. Thus, the purpose of the current study was to discover its pharmacological action for its in vitro antioxidant activity.

Plant-derived flavonoids and terpenoids have received considerable attention in recent years due to their varied pharmacological properties, including antitumor and antioxidant activity. ${ }^{[15]}$ Antioxidants play an important role in scavenging free radicals, thus providing protection against various degenerative diseases. From this point of view, the present study was carried out to evaluate the antioxidant and antitumor activity of the methanol extract of $C$. dichotoma (MECD) against EAC in Swiss albino mice.

\section{MATERIALS AND METHODS}

\section{Plant Materials and Preparation of Extract}

C. dichotoma forst bark was procured from the local forest of Ghaziabad, Uttar Pradesh, India. The seeds were identified at the National Institute of Science Communication and Information Resources (NISCAIR), New Delhi, India (ref. NISCAIR/RHMD/Consult/-2012-13/2025/33). The shaded dried bark of $C$. dichotoma plant was pulverized to a coarse powder, which was initially defatted using petroleum ether and then extracted using methanol, which is then evaporated completely dry to acquire the MECD.

\section{Phytochemical Screening of MECD}

Chemical tests for the screening and identification of bioactive chemical constituents (such as flavonoids, glycosides, steroids, phenols, terpenoids, saponins, resins, tannins, carboxylic acid, coumarins, quinones, and xanthoproteins) in MECD were carried out using the standard procedures. ${ }^{[16-18]}$

\section{Determination of Phenolic and Flavonoid Contents in MECD}

The phenolic contents of MECD were determined as follows: $0.5 \mathrm{~mL}$ aliquot of MECD or gallic acid (standard) was added with $5 \mathrm{~mL}$ of Folin-Ciocalteu reagent and $4 \mathrm{~mL}$ of aqueous sodium carbonate $(1 \mathrm{M})$. After incubation for $15 \mathrm{~min}$ at room temperature, the absorbance was read at $765 \mathrm{~nm}$. The total phenolic contents were expressed in terms of mg equal gallic acid in $1 \mathrm{~g}$ powder of dry plant. ${ }^{[19]}$

Flavonoid contents of MECD were determined as follows: $0.5 \mathrm{~mL}$ of MECD diluted in $1.5 \mathrm{~mL}$ of $95 \%$ methanol solution, $0.1 \mathrm{~mL}$ of $10 \% \mathrm{AlCl}_{3}(\mathrm{w} / \mathrm{v}), 0.1 \mathrm{~mL}$ of $1 \mathrm{M}$ potassium acetate, and $2.8 \mathrm{~mL}$ of distilled water were added. After $30 \mathrm{~min}$ at room temperature, the absorbance was measured at $415 \mathrm{~nm}$. Rutin was used as a positive standard for preparing the standard calibration curve. The total flavonoid contents were measured in terms of $\mathrm{mg}$ equal of rutin in $1 \mathrm{~g}$ powder of the dry plant. ${ }^{[20]}$

\section{Experimental Design}

The guidelines of Committee for the Purpose of Control and Supervision of Experiments on Animals, Government of India, were followed and prior permission was sought from the Institutional Animal Ethics Committee (IAEC), Vide Approval number IAEC/DU/58 dated. 24.09.2013 Dibrugarh University, India, for conducting the study. Albino mice of either sex $(25-30 \mathrm{~g})$ and Albino rats of either sex (160-180 g) were housed in polypropylene cages under controlled conditions (room temperature $25 \pm 2^{\circ} \mathrm{C}$, air humidity $50 \pm 15 \%$, and photoperiod of $12 \mathrm{~h}$ light:dark cycle), and water was provided ad libitum throughout the study. After acclimatization to the environment for 1 week, mice were used for evaluation of anticancer activity while rats were used for the evaluation of antioxidant activity.

\section{Acute Toxicity Study}

The acute toxicity test of the methanol extract of $C$. dichotoma (MECD) was done on Swiss albino mice (40-45 g) as per the fixed dose procedure, OECD 420. ${ }^{[23]}$ The Institutional Animal Ethical Committee permitted using the animals for this purpose. After overnight fasting, the animals were given a fixed maximum dose $2000 \mathrm{mg} / \mathrm{kg}$, body weight through intraperitoneally.

\section{In Vitro Antioxidant Activity}

The in vitro antioxidant activity of the MECD was evaluated with the help of following methods. The 1, 
1-diphenyl-2-picryl hydrazyl (DPPH) radical was employed for the determination of the free-radical scavenging action of the MECD extract. The nitric oxide free-radical scavenging activity was calculated by the method reported previously. The hydrogen peroxide scavenging of methanol extract was determined according to the method reported elsewhere. ${ }^{[24,25]}$ The following equation was employed for the calculation of percentage inhibition:

Percentage inhibition $=\left(\mathrm{A}_{\mathrm{o}}-\mathrm{A}_{\mathrm{t}} / \mathrm{A}_{\mathrm{o}}\right) \times 100$

\section{In Vivo Antioxidant Activity}

The level of malondialdehyde (MDA) (21) and antioxidant enzyme activities, that is, reduced glutathione (GSH) (28), superoxide dismutase (SOD) (16), and catalase (CAT) (6) was measured in the serum. The protein content in the supernatant was measured according to the method reported earlier. ${ }^{[26]}$

\section{In Vitro Anticancer Activity}

\section{MTT assay}

The cells were developed in the RPMI- 1640 medium at $37^{\circ} \mathrm{C}$ in a humified incubator for $6-7 \mathrm{~h}$ under $5 \% \mathrm{CO}_{2}$. The cells were harvested, counted $\left(3 \times 10^{4}\right.$ cells per $\left.\mathrm{mL}\right)$ and transferred into a 24 well plate, incubated for $24 \mathrm{~h}$ before adding the test compound. Then, the serial dilutions of the test samples were prepared by dissolving the compounds in dimethyl sulfoxide (DMSO) followed by the dilution with RPMI-1640 medium to get the final concentration of $100,250,500$, and $1000 \mu \mathrm{g}$ per $\mathrm{mL}$. The stock solutions of the samples were prepared. The sample at $10 \mu \mathrm{L}$ and the cell lines at $90 \mu \mathrm{L}$ were incubated for $72 \mathrm{~h}$. The MTT solution at $5 \mathrm{mg} / \mathrm{mL}$ was dissolved in $1 \mathrm{~mL}$ of phosphate buffer solution, and $10 \mu \mathrm{L}$ of it was added to each of the 24 wells. The wells were wrapped using aluminum foil and incubated for $4 \mathrm{~h}$ at $37^{\circ} \mathrm{C}$. The solution containing media, dead cells and unbend MTT in each of the well were removed by suction and $150 \mu \mathrm{L}$ of DMSO was added in each of the well. Then, the plants were vibrated and the optical density was recorded at $595 \mathrm{~nm}$ using DMSO as blank. The controls and the samples were assayed and replicated for each concentration and for each cell line. After incubation for $24 \mathrm{~h}$ of the mononuclear cells containing the plant extract, the toxicity on the cancer cell lines was estimated using the MTT assay. The toxicity was obtained by comparing the absorbance between the control and samples. Then, the values were used to calculate the concentration of plant extract needed to cause a $50 \%$ decrease $\left(\mathrm{IC}_{50}\right)$ a growth (cell number) in EAC cell lines. ${ }^{[27]}$

$$
\text { Cell viability }(\%)=\text { Mean OD } / \text { Control OD } \times 100
$$

\section{Sulforhodamine B (SRB) assay}

The anticancer action of the MECD was assessed under two cell lines. Cell lines were developed in the RPMI 1640 medium having $10 \%$ of the fetal bovine serum and $2 \mathrm{mM}$ of L-glutamine. For this study, the cells were inoculated in 96 well plates with $90 \mu \mathrm{L} /$ well at appropriate plating densities, depending on the doubling time of the individual cell lines. After the inoculation of cell, the microtiter plates were incubated in $5 \% \mathrm{CO}_{2}$ and $95 \%$ air at $37^{\circ} \mathrm{C}$ and $100 \%$ relative humidity for $24 \mathrm{~h}$ before adding the test drugs.

After completion of $24 \mathrm{~h}$ incubation, the cells from one plate of each of the cell lines were fixed in situ with TCA to represent the measurement of the cell population for every cell line at the time of adding the drug (Tz). The experimental drugs were solubilized in an appropriate solvent to 400-folds the desired maximum test concentration and stored in the fridge before use. At the time of addition of the drug, aliquot of the frozen concentrate was then thawed and subsequently diluted to 10 times the maximum test concentration with the medium containing test article at the concentration of $100,200,400$, and $800 \mu \mathrm{g} / \mathrm{mL}$. The aliquots of $10 \mu \mathrm{L}$ of the different dilutions were included to the appropriate wells already having $90 \mu \mathrm{L}$ of the cell suspension, resulting in final drug concentrations of $10,20,40$, and $80 \mu \mathrm{g} / \mathrm{mL}$. For each experiment, a recognized anticancer medicament, doxorubicin was employed as a positive control.

After the addition of the test compound, the plates were incubated at the standard conditions for $48 \mathrm{~h}$, and the assay was terminated by adding cold TCA. The cells were fixed in situ by gently adding $50 \mu \mathrm{L} 30 \% \mathrm{w} / \mathrm{v}$ cold TCA making final concentration $10 \%$, and then incubated at $4{ }^{\circ} \mathrm{C}$ for $1 \mathrm{~h}$. Supernatant was then discarded; plates were washed 5 times with tap water and then air dried. The solution of SRB $(50 \mu \mathrm{L})$ at $0.4 \% \mathrm{w} / \mathrm{v}$ in acetic acid $(1 \%)$ was added to each well and the plates were incubated at room temperature for $20 \mathrm{~min}$. After the staining, the unbound dye was recovered and residual dye was eliminated by washing 5 times with acetic acid. Plates were air dried and bound stain was consequently eluted with $10 \mathrm{mM}$ Trizam base and absorbance was read at $540 \mathrm{~nm}$ with the $690 \mathrm{~nm}$ reference wavelength. The percentage growth was calculated on a plate by plate basis for the test wells relative to the control wells. The percentage growth was expressed as ratio the average absorbance of test well to average absorbance of control wells multiplied by 100 .

Using these six absorbance measurements (time zero [Tz], the control growth [C], and the test growth in the presence of drug at four concentration levels [Ti]); percentage growth was assessed at every drug concentration level. The percentage growth inhibition was evaluated as:

$([\mathrm{Ti}-\mathrm{Tz}] /[\mathrm{C}-\mathrm{Tz}]) \times 100$ for the concentrations for which $\mathrm{Ti} \geq \mathrm{Tz}(\mathrm{Ti}-\mathrm{Tz})$ positive or zero $([\mathrm{Ti}-\mathrm{Tz}] / \mathrm{Tz}) \times 100$ for the concentrations for which $\mathrm{Ti}<\mathrm{Tz}(\mathrm{Ti}-\mathrm{Tz})$ negative.

Dose-response parameters were estimated for every test object. The growth inhibition of $50 \%\left(\mathrm{GI}_{50}\right)$ was evaluated 
from $([\mathrm{Ti}-\mathrm{Tz}] /[\mathrm{C}-\mathrm{Tz}]) \times 100=50$, which is drug concentration leading to $50 \%$ decrease in net protein elevation (as determined by SRB staining) in the control cells during incubation process. The concentration of drug causing the total growth inhibition (TGI) was evaluated from $\mathrm{Ti}=\mathrm{Tz}$. The concentration of the drug causing $50 \%$ decrease in measured protein at the end of the treatment of drug as compared to that the start $\left(\mathrm{LC}_{50}\right)$, indicate a net loss of the cells after the treatment is calculated from $([\mathrm{Ti}-\mathrm{Tz}] / \mathrm{Tz}) \times 100=-50$.

Values were evaluated for each of the three parameters, if the activity level was reached; but it effect was not reached or was surpassed, values for parameter were expressed as higher or lower than the maximum or minimum concentration tested. The synopsis of the parameters is as follows:

- $\mathrm{GI}_{50}$ : Concentration of drug causing a $50 \%$ inhibition in the net protein increase

- TGI: Concentration of drug causing total inhibition growth

- $\mathrm{LC}_{50}$ : Concentration of drug causing $50 \%$ reduction in measured protein at the end of drug treatment in comparison to the beginning. ${ }^{[28]}$

\section{In Vivo Anticancer Activity}

EAC cells were cultured in the peritoneal cavity of healthy albino mice weighing $25-30 \mathrm{~g}$ by administering a suspension of EAC cells $\left(1 \times 10^{6}\right.$ cells per $\left.\mathrm{mL}\right)$ intraperitoneally. The cells were aspirated aseptically from the peritoneal cavity of the mice on $15^{\text {th }}$ day and washed with normal saline and centrifuged at $1500 \mathrm{rpm}$ for $15 \mathrm{~min}$. The pellet was re-suspended with normal saline and the process was repeated 3 times. Finally, the cells were suspended in a known quantity of normal saline and the cell count was adjusted to $2 \times 10^{6}$ cells per $\mathrm{mL}$. The sample showing more than $90 \%$ viability was used for transplantation. Each animal received $0.5 \mathrm{~mL}$ of tumor cell suspension containing $2 \times 10^{6}$ cells intraperitoneally. ${ }^{[29]}$

\section{Statistical Analysis}

The data are expressed as means \pm S.E.M. All statistical analyses were performed using Graph-Pad InStat version 3.06 (GraphPad Software). All data were analyzed using a one-way analysis of variance followed by Dunnett's test. The results were considered statistically significant when $P<0.05$.

\section{RESULTS}

\section{Phytochemical Analysis}

The MECD showed the presence of steroid, carbohydrate, alkaloid, saponin, cardiac glycosides, flavonoid, and phenolic compounds.

\section{Determination of Phenolic and Flavonoid Contents}

The phenolic [Figure 1] and the flavonoid contents [Figure 2] of the MECD elevated with an increase in the concentration, with values of 48.75 and $63.5 \mu \mathrm{g} / \mathrm{ml}$, respectively.

\section{Acute Toxicity}

From the study, it was observed that the animals have not shown any overt signs of toxicity. Both CNS and peripheral effects were not observed. No mortality was found in animals after $48 \mathrm{~h}$. Thus, the dose $2000 \mathrm{mg} / \mathrm{kg}$ body weight is found to be safe and the two doses of MECD were used for additional analyses.

\section{In Vitro Antioxidant Activity}

The significant reduction in the DPPH radical concentration was detected due to the free-radical scavenging capacity of MCED. The antioxidant action elevated with elevated concentration of the MECD, exhibited as the minimum inhibitory concentration of the MECD that inhibited 50\% of the free radicals $\left(\mathrm{IC}_{50}\right)$ to be $62.46 \mu \mathrm{g} / \mathrm{ml}$ while the documented $\mathrm{IC}_{50}$ value for the standard (ascorbic acid) was $27.66 \mu \mathrm{g} / \mathrm{ml}(24)$ [Figure 3].

The MECD considerably inhibited the nitric oxide content in a dose-dependent manner with an $\mathrm{IC}_{50}$ value of $254.13 \mu \mathrm{g} / \mathrm{ml}$. This nitric oxide antioxidant activity could be due to the phenolic and polyphenolic contents present in the MECD [Figure 4]. The $\mathrm{IC}_{50}$ of the MECD was found to be

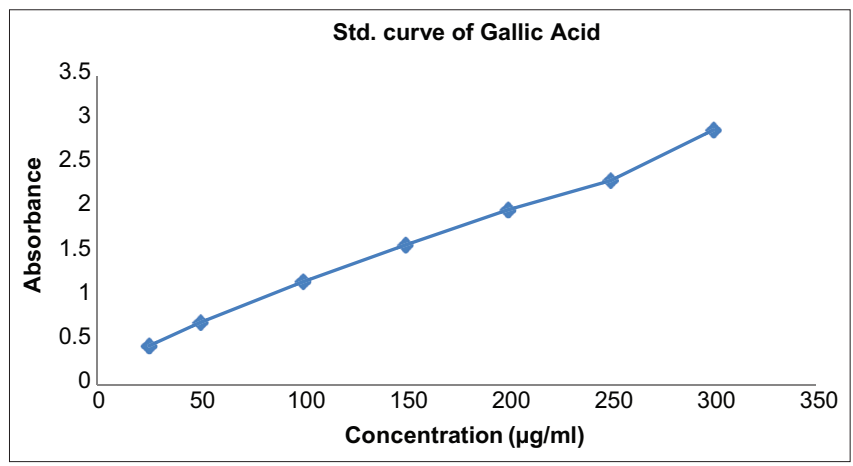

Figure 1: Total phenolic content

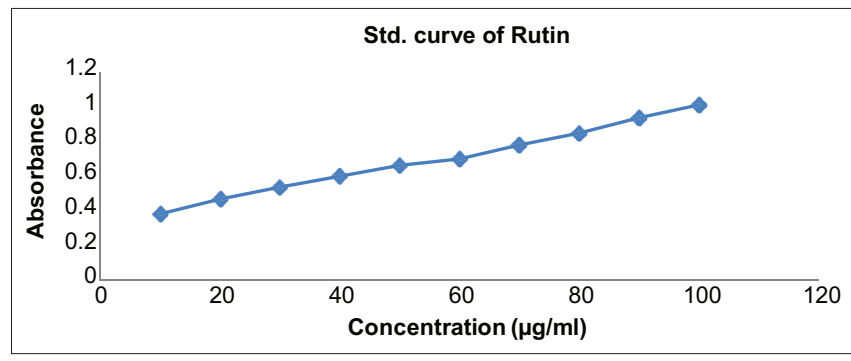

Figure 2: Total flavonoid content 
$254.13 \mu \mathrm{g} / \mathrm{ml}$ and the $\mathrm{IC}_{50}$ of the standard was found to be $104.45 \mu \mathrm{g} / \mathrm{ml}$, the protecting ability against formation of nitric oxide radical. The MECD also showed $\mathrm{H}_{2} \mathrm{O}_{2}$ degradation activity in a concentration-dependent fashion with the $\mathrm{IC}_{50}$ value, $236.5 \mu \mathrm{g} / \mathrm{ml}$, and the $\mathrm{IC}_{50}$ of the standard was found to be $47.05 \mu \mathrm{g} / \mathrm{ml}$ [Figure 5].

\section{In Vivo Antioxidant Activity}

Figure 6 represents the levels of oxidative stress marker MDA, while Table 1 represents the levels of oxidative stress markers (GSH, SOD, and CAT) in serum. A marked increase of MDA levels (lipid peroxidation) and decrease of antioxidant enzyme status (GSH, SOD, and CAT) were observed in the serum of rats in control group when compared with normal control group. MECD (250 and $500 \mathrm{mg} / \mathrm{kg} \mathrm{b.w.)}$ treatment significantly $(P<0.01)$ decreases the MDA levels

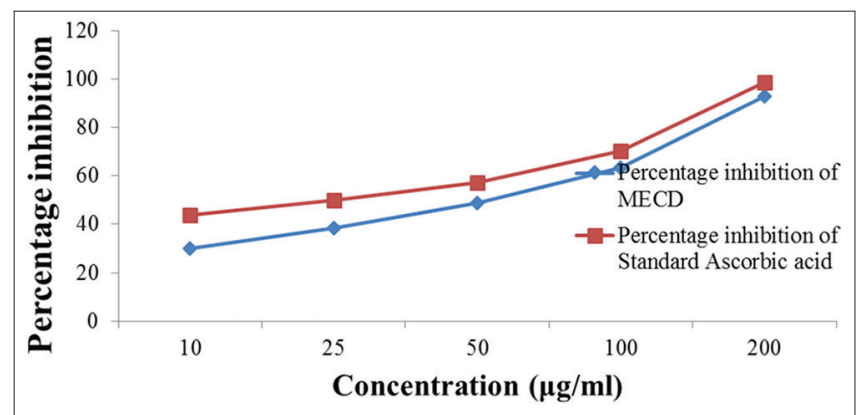

Figure 3: 1, 1-Diphenyl-2-picryl hydrazyl radical scavenging activity

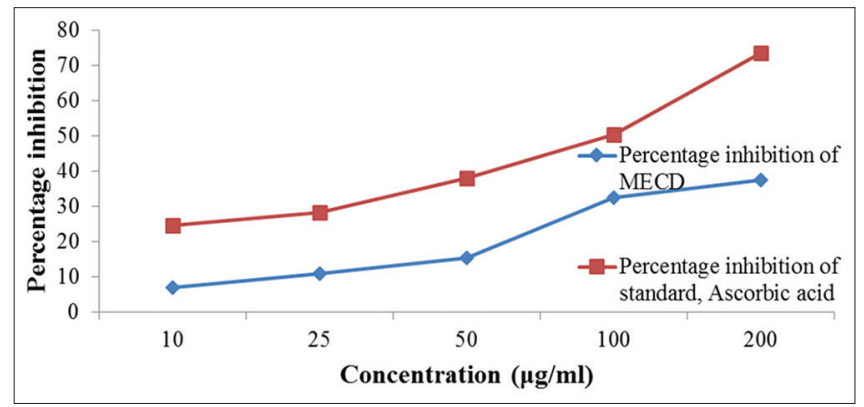

Figure 4: Nitric oxide scavenging activity

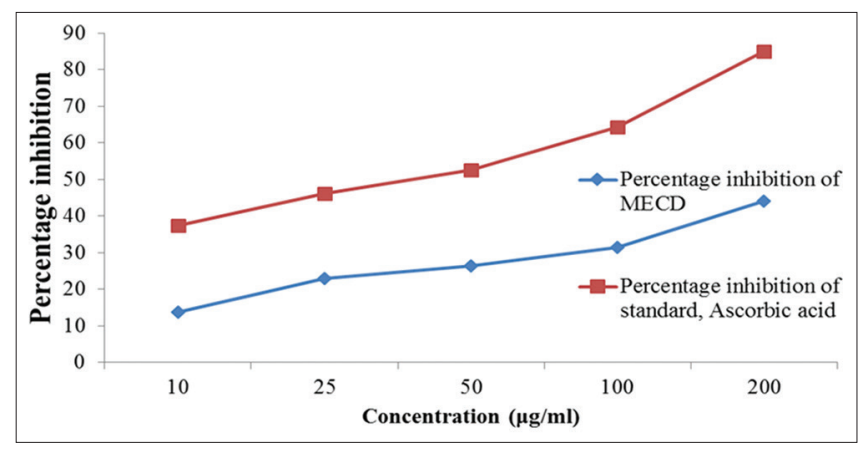

Figure 5: $\mathrm{H}_{2} \mathrm{O}_{2}$ radical scavenging activity and restored the antioxidant enzyme (GSH, SOD, and CAT) activity. The results were comparable to the standard drug, ascorbic acid (5 mg/kg b.w.).

\section{In Vitro Anticancer Activity}

Table 2 represents the effect of MECD on MTT assay on MDA-MB-231 cell line and MCF-7 cell line. Increase in the concentration of MECD dose-dependently increased the percent cytotoxicity and decreased the cell viability in both cell line types. The results with MECD were comparable to the tamoxifen. SRB method is adopted for evaluating the tumor cell suppression activity on the growth inhibition of $50 \%$ (GI50), TGI and lethal concentration 50\% (LC50). Table 3 shows the potential anti-proliferative activity of MECD on selected cell lines MCF-7 and MDA-MB-231. The methanolic extract of $C$. dichotoma shows highest activity against MCF7, followed by MDA-MB-231 cell line. The results obtained with MECD were comparable to doxorubicin.

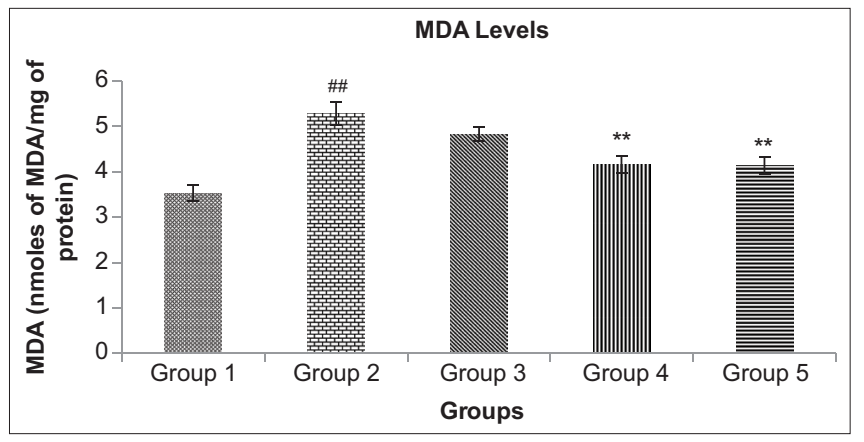

Figure 6: Effect of MECD on malondialdehyde levels. Results are expressed as mean \pm S.E.M. $(n=6)$; ${ }^{\#} P<0.01$ compared to normal control; ${ }^{\star} P<0.05$ and ${ }^{* *} P<0.01$ compared to control; Group 1: Normal control; Group 2: Toxic (alloxan) control; Group 3: MECD, 250 mg/kg b.w.; Group 4: MECD, 500 mg/kg b.w.; Group 5: ascorbic acid, 5 mg/kg. MECD: Methanolic extract of Cordia dichotoma

\begin{tabular}{|c|c|c|c|}
\hline Groups & $\begin{array}{c}\text { Reduced GSH } \\
(\mu \text { moles of } \\
\text { GSH/mg protein })\end{array}$ & $\begin{array}{c}\text { SOD (U/mg } \\
\text { protein) }\end{array}$ & $\begin{array}{c}\text { CAT (U/mg } \\
\text { protein) }\end{array}$ \\
\hline Group 1 & $4.99 \pm 0.17$ & $3.79 \pm 0.13$ & $5.09 \pm 0.18$ \\
\hline Group 2 & $3.11 \pm 0.14^{\# \#}$ & $2.20 \pm 0.26^{\# \#}$ & $2.01 \pm 0.25^{\# \#}$ \\
\hline Group 3 & $4.82 \pm 0.18^{* *}$ & $4.08 \pm 0.25^{* *}$ & $4.85 \pm 0.23^{* *}$ \\
\hline Group 4 & $5.58 \pm 0.12^{* *}$ & $4.75 \pm 0.20^{\star *}$ & $5.07 \pm 0.13^{* *}$ \\
\hline Group 5 & $4.25 \pm 0.18^{* *}$ & $3.93 \pm 0.25^{* *}$ & $3.62 \pm 0.24^{* *}$ \\
\hline
\end{tabular}

Results are expressed as mean \pm S.E.M. $(n=6) ;{ }^{\#} P<0.01$ compared to normal control; ${ }^{*} P<0.05$ and ${ }^{* *} P<0.01$ compared to control; Group 1: Normal control; Group 2: Toxic control; Group 3: MECD, 250 mg/kg b.w.; Group 4: MECD, 500 mg/kg b.w.; Group 5: ascorbic acid, $5 \mathrm{mg} / \mathrm{kg}$. GSH: Glutathione, SOD: Superoxide dismutase, CAT: Catalase, MECD: Methanolic extract of Cordia dichotoma 


\section{In Vivo Anticancer Activity}

There were significant falls in the red blood cell (RBC) count and hemoglobin $(\mathrm{Hb})$ content, and significant increase in white blood cell (WBC) count in the EAC control mice as compared to normal control mice. Treatment with MECD ( $500 \mathrm{mg} / \mathrm{kg}$, b.w., p.o.) or 5 -fluorouracil ( $20 \mathrm{mg} / \mathrm{kg}$ b.w., i.p.) in EAC-cell bearing mice caused a significant $(P<0.01)$ increase in $\mathrm{Hb}$ levels, while MECD (250 mg/kg, b.w., p.o.) treatment had no significant $(P>0.01)$ effect on Hb levels as compared to EAC control group. Similarly, MECD (250 or $500 \mathrm{mg} / \mathrm{kg}$, b.w., p.o.) treatment had no significant $(P>0.01)$ effect on RBC content as compared to EAC control group. Treatment with MECD (250 or $500 \mathrm{mg} / \mathrm{kg}$, b.w., p.o.) or 5 -fluorouracil $(20 \mathrm{mg} / \mathrm{kg}$ b.w., i.p.) in EAC-cell bearing mice caused a significant $(P<0.01)$ decrease in WBC levels compared to EAC control rats [Table 4].

Table 5 shows the effect of MECD on tumorigenic parameters. The maximum gain of body weight was observed in the EAC control group. In the case of MECD and 5-fluorouracil treated groups, the body weight was significantly $(P<0.01)$ reduced. The tumor volume and tumor weight were found to be significantly $(P<0.05$ or $P<0.01)$ decreased in MECD treated animals at the doses 250 and $500 \mathrm{mg} / \mathrm{kg}$ and 5-fluorouracil $(20 \mathrm{mg} / \mathrm{kg})$ when compared with EAC control animals. The days of survival were recorded in the EAC bearing mice administered with MECD and 5-fluorouracil. With MECD treatment, the survival of EAC bearing mice significantly $(P<0.01)$ increased as compared to EAC bearing control group. In treated group, MST was significantly increased to $29.0 \pm 1.98$ (\%ILS $=69.04), 34.12$ $\pm 1.84(\% \mathrm{ILS}=81.25)$, and $36.87 \pm 1.67(\% \mathrm{ILS}=87.79)$, respectively, when compared to EAC control group.

\section{DISCUSSION}

Cancer-related morbidity and mortality is a serious concern despite significant advancements in chemotherapeutic agents. However, preventive agents are few and are of limited use. ${ }^{[30]}$ The present study evaluated the antitumor activity of MECD against EAC induced in mice. The study indicated significant increase in body weight following inoculation of EAC cells to EAC control mice. The increased body weight in mice bearing EAC tumor may be due to accumulation of ascetic fluid inducing an intense edema formation. ${ }^{[31-33]}$ In the present study, anticancer effect of MECD is observed by attenuation of EAC-induced weight gain, decreased tumor volume and tumor weight. Further, a reliable criterion for judging the value of anticancer agent is the prolongation of life span of animals. ${ }^{[34]}$ The mean survival of MECD treated EAC mice was increased indicating the prolongation of life span of animals. In the present study, it was observed that MECD has

\begin{tabular}{lcccc} 
Concentrations & \multicolumn{2}{c}{ Table 2: MTT assay for MECD forst bark and tamoxifen } & \\
& $\begin{array}{c}\text { \% of cell viability on } \\
\text { MDA-MB-231 cell line }\end{array}$ & $\begin{array}{c}\text { \% of cytotoxicity on } \\
\text { MDA-MB-231 cell line }\end{array}$ & $\begin{array}{c}\text { \% of cell viability } \\
\text { on MCF-7 cell line }\end{array}$ & $\begin{array}{c}\text { \% of cytotoxicity } \\
\text { on MCF-7 cell line }\end{array}$ \\
\hline MECD $(\mu \mathrm{g} / \mathrm{mL})$ & & & & \\
Control & 100 & 0 & 100 & 0 \\
25 & 90.2 & 9.8 & 88.3 & 11.7 \\
50 & 87.3 & 12.7 & 82.5 & 17.5 \\
100 & 68.4 & 31.6 & 60.3 & 39.7 \\
300 & 45.4 & 54.6 & 40.5 & 59.5 \\
500 & 30.6 & 69.4 & 27.9 & 72.1 \\
Tamoxifen $(\mu \mathrm{g} / \mathrm{mL})$ & & & & 0 \\
Control & 100 & 0 & 100 & 29.4 \\
10 & 79.7 & 20.3 & 70.6 & 57.5 \\
25 & 70.6 & 29.4 & 42.5 & 74.4 \\
50 & 42.2 & 57.8 & 25.6 & 84.1 \\
100 & 22.9 & 77.1 & 15.9 & \\
\hline
\end{tabular}

MECD: Methanolic extract of Cordia dichotoma

Table 3: Anti-proliferative activity of MECD forst bark and doxorubicin on breast cancer cell lines

\begin{tabular}{|c|c|c|c|c|c|c|}
\hline \multirow[t]{2}{*}{ Test drugs } & \multicolumn{3}{|c|}{ MCF-7 cell line $(\mu \mathrm{g} / \mathrm{mL})(n=3)$} & \multicolumn{3}{|c|}{ MDA-MB-231 cell line $(\mu \mathrm{g} / \mathrm{mL})(n=3)$} \\
\hline & GI 50 & TGI & LC 50 & GI 50 & TGI & LC 50 \\
\hline MECD & 30.6 & 65.5 & $>80$ & 49.7 & $>80$ & $>80$ \\
\hline Doxorubicin & $<10$ & $<10$ & $<10$ & $<10$ & $<10$ & $<10$ \\
\hline
\end{tabular}


excellent antioxidant and free-radical scavenging properties which may be responsible for the anticancer effect.

Excessive production of free radicals leads to lipid peroxidation, which may cause degeneration of tissues and oxidative stress. ${ }^{[35]}$ The inhibition of SOD activity results due to tumor growth (17). The decrease in SOD activity in EAC bearing mice might be due to loss of slight SOD activity in EAC cells and mitochondrial loss. ${ }^{[36]}$ Free-radical scavengers (SOD and CAT) are present in oxygen metabolizing cells and provide defense against damaging effects of superoxide and hydrogen peroxide. ${ }^{[37]}$ MECD decreased the lipid peroxidation and restored the antioxidant enzyme (GSH, SOD, and CAT) activity which indicates the antioxidant and free radical scavenging property of MECD. As MECD showed excellent antioxidant and free-radical scavenging properties that can induce cell death in cancer cells. The treatment also decreased number of actively dividing cells (increased the percent cytotoxicity and decreased the cell viability), both in MDA-MB-231 and MCF-7 cells. Apoptosis is a common mode of action of chemotherapeutic agents including plant derived natural products. Its induction is the key to success of plant-derived natural products as anticancer agents. ${ }^{[38]}$ MECD could specifically induce apoptosis of cancer cells indicating its potential anticancer activity.

Table 4: Effect of MECD forst bark on hematological parameters of EAC cells bearing mice

\begin{tabular}{lccc} 
Treatment & $\mathbf{H b}(\mathbf{g} / \mathbf{d L})$ & $\begin{array}{c}\mathbf{R B C} \\
\left(\mathbf{1 0 ^ { 6 }} \mathbf{c e l l s} / \mathbf{m m}^{3}\right)\end{array}$ & $\begin{array}{c}\text { WBC }\left(\mathbf{~ 1 0}^{3}\right. \\
\left.\mathbf{c e l l s} / \mathbf{m m}^{3}\right)\end{array}$ \\
\hline Group 1 & $14.23 \pm 0.14$ & $5.30 \pm 0.05$ & $7.03 \pm 0.08$ \\
Group 2 & $7.30 \pm 0.55^{\# \#}$ & $3.00 \pm 0.28^{\# \#}$ & $13.23 \pm 0.43^{\# \#}$ \\
Group 3 & $8.03 \pm 0.26$ & $3.15 \pm 0.09$ & $11.23 \pm 0.20^{\star *}$ \\
Group 4 & $9.90 \pm 0.05^{\star *}$ & $3.90 \pm 0.05$ & $10.56 \pm 0.38^{\star *}$ \\
Group 5 & $11.36 \pm 0.40^{\star *}$ & $4.36 \pm 0.55^{\star *}$ & $8.46 \pm 0.42^{* *}$ \\
\hline
\end{tabular}

Results are expressed as mean \pm S.E.M. $(n=6) ;{ }^{\# \#} P<0.01$ compared to normal control; ${ }^{*} P<0.05$ and ${ }^{* *} P<0.01$ compared to toxic control; Group 1: Normal control $(0.1 \% \mathrm{NaCl})$; Group 2: Toxic control (EAC cells $\left(2 \times 10^{6}\right)$ with $\mathrm{NaCl}$ solution i.p.); Group 3: EAC cells $\left(2 \times 10^{6}\right)$ with MECD (250 mg/kg b.w., p.o.); Group 4: EAC cells $\left(2 \times 10^{6}\right)$ with MECD $(500 \mathrm{mg} / \mathrm{kg}$ b.w., p.o.); Group 5: EAC cells $\left(2 \times 10^{6}\right)$ with 5 -Fluorouracil $(20 \mathrm{mg} / \mathrm{kg}$ b.w., i.p.). EAC: Ehrlich's Ascites Carcinoma, MECD: Methanolic extract of Cordia dichotoma
The hematological parameters of EAC tumor-bearing mice were significantly changed from those of the normal group. There were significant decreases in $\mathrm{Hb}$ levels and RBCs count and an increase in WBCs. A similar effect of EAC inoculation on hematological parameters of the animals bearing tumor has been reported in the previous studies. ${ }^{[39-41]}$ Treatment with MECD brought back the $\mathrm{Hb}$ content and WBCs count to normal levels.

Plant-derived extracts containing antioxidant principles have shown cytotoxicity toward tumor cells and antitumor activity in experimental animals. ${ }^{[38,39]}$ The lowering of lipid peroxidation and increase in levels of GSH, SOD, and CAT in MECD-treated group indicates its potential as an inhibitor of EAC induced intracellular oxidative stress. The antioxidant activity of MECD is generally attributed to its content of quercetin and rutin as phytochemical isolation studies with MECD have shown that the extract contains rutin and quercetin. The decrease of lipid peroxidation and increase in levels of GSH and SOD following the administration of MECD indicates its potential as an inhibitor of EAC induced intracellular oxidative stress.

Antioxidants are the set of substances, which reduce or impede the oxidative progression. Many of the possible harmful outcomes of oxygen are because of the development and action of several chemical constituents, called as the reactive oxygen species (ROS), which have the propensity to give oxygen to other compounds. Most of such reactive entities are basically free radicals in nature. The types of free radicals compounds comprise the superoxide $\left(\mathrm{O}_{2}\right)$, hydroxyl $\left(\mathrm{OH}^{-}\right)$, the lipid peroxy (LOO), and nitric oxide (NO) free radical. This oxidative stress is an important etiological aspect concerned in many of the chronic human disorder such as cancer, diabetes mellitus, and aging. It has been stated that the antioxidant capacity of plants might be because of their phenolic contents. The flavonoids are a class of polyphenolic compounds with recognized properties, which comprise the inhibition of oxidative and hydrolytic enzymes, free-radical scavenging, and the anti-inflammatory activity. Most of the antioxidant action might be due to the presence of anthocyanin, catechin, coumarins, flavones, flavonoids, isocatechin, isoflavones, and lignans. ${ }^{[42-44]}$

Table 5: Effect of MECD forst bark on tumorigenic parameters of EAC cells bearing mice

\begin{tabular}{|c|c|c|c|c|c|}
\hline Treatment & Increase in body weight (g) & MST (days) & ILS (\%) & Tumor volume $(\mathrm{mL})$ & Tumor weight (g) \\
\hline Group 1 & - & - & - & - & - \\
\hline Group 2 & $8.26 \pm 0.14$ & $19.25 \pm 0.67$ & 45.83 & $9.06 \pm 0.27$ & $7.93 \pm 0.23$ \\
\hline Group 3 & $7.30 \pm 0.2^{* *}$ & $29.0 \pm 1.98^{\star \star}$ & 69.04 & $7.73 \pm 0.39^{\star *}$ & $7.23 \pm 0.14^{*}$ \\
\hline Group 4 & $6.70 \pm 0.25^{\star \star}$ & $34.12 \pm 1.84^{\star \star}$ & 81.25 & $6.80 \pm 0.15^{\star \star}$ & $6.53 \pm 0.14^{\star *}$ \\
\hline Group 5 & $5.83 \pm 0.23^{* *}$ & $36.87 \pm 1.67^{\star *}$ & 87.79 & $6.16 \pm 0.20^{* *}$ & $4.33 \pm 0.17^{\star *}$ \\
\hline
\end{tabular}

Results are expressed as mean \pm S.E.M. $(n=6) ;{ }^{*} P<0.05$ and ${ }^{* *} P<0.01$ compared to toxic control; Group 1 : Normal control $(0.1 \%$ NaCl); Group 2: Toxic control (EAC cells $\left(2 \times 10^{6}\right)$ with $\mathrm{NaCl}$ solution i.p.); Group 3: EAC cells $\left(2 \times 10^{6}\right)$ with MECD $(250 \mathrm{mg} / \mathrm{kg}$ b.w., p.o.); Group 4: EAC cells $\left(2 \times 10^{6}\right)$ with MECD $\left(500 \mathrm{mg} / \mathrm{kg}\right.$ b.w., p.o.); Group 5: EAC cells $\left(2 \times 10^{6}\right)$ with 5-Fluorouracil (20 mg/kg b.w., i.p.). EAC: Ehrlich's Ascites Carcinoma, MECD: Methanolic extract of Cordia dichotoma 


\section{CONCLUSION}

The results of the current study propose that the antitumor activity of MECD can be inferred from the increased life span of EAC bearing mice, which is due to its antioxidant activity. Thus, the present study clearly indicates that MECD could be a novel chemotherapeutic agent for human cancer because of its promising activity and may be considered for further clinical studies in drug development. The further study has to be extended for carrying out the mode of action of the plant extract on the cancer cell lines at the molecular level.

\section{REFERENCES}

1. Abdallah IZ, Khattaba HA, Heebab GH. Gastroprotective effect of Cordia myxa L. fruit extract against indomethacin-induced gastric ulceration in rats. Life Sci J 2011;8:433-45.

2. Al-Musayeib N, Perveen S, Fatima I, Nasir M, Hussain A. Antioxidant, anti-glycation and anti-inflammatory activities of phenolic constituents from Cordia sinensis. Molecules 2011;16:10214-26.

3. Bhattacharya S, Prasanna A, Majumdar P, Kumar RB, Haldar PK. Antitumor efficacy and amelioration of oxidative stress by Trichosanthes dioica root against Ehrlich ascites carcinoma in mice. Pharm Biol 2011;9:927-35.

4. Chen L, Watkins JF. Evidence against the presence of H2 histocompatibility antigens in Ehrlich ascites tumour cells. Nature 1970;225:734-5.

5. Chunekar. Bhavaprakash Nighantu. Varanasi: Chaukhamba Bharati Academy; 1999.

6. Claiborne AL. Catalase activity. In: CRC Handbook of Methods for Oxygen Radical Research. Boca Raton, Florida: CRC Press; 1985. p. 283-4.

7. Gupta M, Mazumder UK, Kumar RS, Kumar TS. Antitumor activity and antioxidant role of Bauhinia racemosa against Ehrlich ascites carcinoma in Swiss albino mice. Acta Pharmacol Sin 2004;25:1070-6.

8. Harborne JB. Methods of plant analysis. In: Phytochemical Methods. London: Chapman and Hall; 1973.

9. Hegazi A, Al Tahtawy RH, Allah FA, Abdou AM. Antitumor and antioxidant activity of honey in mice bearing Ehrlich ascites carcinoma. Acad J Cancer Res 2014;7:208-14.

10. Jamkhande PG, Sonal RB, Shailesh LP, Priti ST. Plant profile, phytochemistry and pharmacology of Cordia dichotoma (Indian cherry): A review. Asian Pac J Trop Biomed 2013;3:1009-12.

11. Kameshwaran S, Suresh V, Arunachalam G, S. Kanthlal SK, Mohanraj M. In vitro and in vivo anticancer activity of methanolic flower extract of Tecoma stans flower. Int Res J Pharm 2012;3:246-52.

12. Kuppast IJ, Nayak PV. Wound healing activity of Cordia dichotoma Forst. f. fruits. Indian J Nat Prod Resour
2006;5:99-102.

13. Kuppasta IJ, Nayak PV. Anthelmintic activity of fruits of Cordia dichotoma. Indian J Nat Prod Resour 2003;19:27-9.

14. Lowry OH, Rosebrough NJ, Farr AL, Randall RJ. Protein measurement with the folin phenol reagent. J Biol Chem 1951;193:265-75.

15. Madhubanti B, Pralay M, Sujata M. Inhibition of Ehrlich's ascites carcinoma by the leaf extracts of Eupatorium ayapana in Swiss albino mice. Res J Pharm Biol Chem Sci 2015;6:549-52.

16. Marklund S, Marklund G. Involvement of the superoxide anion radical in the autoxidation of pyrogallol and a convenient assay for superoxide dismutase. Eur J Biochem 1974;47:469-74.

17. Marklund SL, Westman NG, Lundgren E, Roos G. Copper and zinc containing superoxide dismutase, manganese-containing superoxide dismutase, catalase and glutathione peroxidase in normal and neoplastic human cell lines and normal human tissues. Cancer Res 1982;42:1955-61.

18. Mishra A, Garg GP. Antidiabetic activity of fruit pulp of Cordia dichotoma in alloxan induced diabetic rats. Int $\mathrm{J}$ Sci Pharm Res 2011;2:2314-9.

19. Bharath BK, Selvasubramanian. Antitumor activity of Aloe vera against Ehrlich ascitis carcinoma (EAC) in Swiss albino mice. Int J Pharm Biol Sci 2011;2:400-9.

20. Noureldeen AF, Gashlan HM, Al-Ghamdi NA, Ramadan RM. In vivo antitumor activity of Bis (4-bromobenzaldehyde-4-iminacetophenone) tetraaquochromium (III) sulphate complex against Ehrlich ascites carcinoma cells induced in mice. Res J Pharm Biol Chem Sci 2017;8:1406-14.

21. Ohkawa H, Ohishi N, Yagi K. Assay for lipid peroxides in animal tissues by thiobarbituric acid reaction. Anal Biochem 1979;95:351-8.

22. Pandya NB, Tigari P, Dupadahalli K, Kamurthy H, Nadendla RR. Antitumor and antioxidant status of Terminalia catappa against Ehrlich ascites carcinoma in Swiss albino mice. Indian J Pharmacol 2013;45:464-9.

23. Parekh J, Chands S. Phytochemical screening of some plants from Western regions of India. Plant Arch 2008;8:657-62.

24. Pourmorad F, Hosseinimehr SJ, Shahabimajd N. Antioxidant activity, phenol and flavonoid contents of some selected Iranian medicinal plants. Afr J Biotechnol 2006;5:1142-5.

25. Purushoth PT, Panneerselvam P, Selvakumari S, Sivaraman D. In vitro and in vivo anticancer activity of ethanolic extract of Canthium parviflorum Lam on DLA and Hela cell lines. Int J Drug Dev Res 2011;3:280-5.

26. Ragasa CY, Sylvia U, Virgilio E. Chemical constituents of Cordia dichotoma G. Forst. J Appl Pharm Sci 2015;5:16-21.

27. Samudrala PK, AugustineBB, Kasala ER, Bodduluru LN, Barua C, Lahkar M. Evaluation of antitumor activity and antioxidant status of Alternanthera brasiliana 
against Ehrlich ascites carcinoma in Swiss albino mice. Pharmacogn Res 2015;7:66-73.

28. Sedlak J, Lindsay RH. Estimation of total, proteinbound, and nonprotein sulfhydryl groups in tissue with Ellman's reagent. Anal Biochem 1968;25:192-205.

29. Skehan P, Storeng R, Scudiero D, Monks A, McMahon J, Vistica D, et al. New colorimetric cytotoxicity assay for anticancer-drug screening. J Natl Cancer Inst 1990;82:1107-12.

30. Sofowora A. Medicinal plants and traditional medicine in Africa. Hoboken, New Jersey: John Wiley and Sons Limited; 1993. p. 96-106.

31. Sreelatha S, Jeyachitra A, Padma PR. Antiproliferation and induction of apoptosis by Moringa oleifera leaf extract on human cancer cells. Food Chem Toxicol 2011;49:1270-5.

32. Sun Y, Oberley LW, Elwell JH, Rivera ES. Antioxidant enzyme activities in normal and transformed mice liver cells. Int J Cancer 1989;44:1028-33.

33. Trease GE, Evans WC. Pharmacognosy. $15^{\text {th }}$ ed. Philadelphia, Pennsylvania, PA: Saunders; 2002. p. 214-393.

34. Junejo JA, Zaman K, Rudrapal M, Hussain N. Antidiabetic and antioxidant activity of hydro-alcoholic extract of Oxalis debilis Kunth leaves in experimental rats. Biosci Biotech Res Commun 2020;13:860-7.

35. Junejo JA, Rudrapal M, Zaman K. Antidiabetic activity of Carallia brachiata Lour. leaves hydro-alcoholic extract (HAE) with antioxidant potential in diabetic rats. Indian J Nat Prod Resour 2020;11:18-29.

36. Junejo JA, Zaman K, Rudrapal M, Khan A, Sarwa KK, Suryawanshi VK, et al. Antidiarrheal and antipyretic activity of ethyl acetate and hydro-alcoholic extracts of Diplazium esculentum leaves. Biosci Biotech Res Comm 2020;13:169-73.
37. Junejo JA, Gogoi G, Islam J, Rudrapal M, Mondal P, Hazarika $\mathrm{H}$, et al. Exploration of antioxidant, antidiabetic and hepatoprotective activity of Diplazium esculentum, a wild edible plant from North Eastern region of India. Future J Pharm Sci 2018;4:93-101.

38. Junejo JA, Rudrapal M, Nainwal LM, Zaman K. Antidiabetic activity of hydro-alcoholic stem bark extract of Callicarpa arborea Roxb. with antioxidant potential in diabetic rats. Biomed Pharmacother 2017;95:84-94.

39. Junejo JA, Mondal P, Rudrapal M, Zaman K. Antidiabetic assessment of the hydro-alcoholic leaf extracts of the plant Tetrastigma angustifolia (Roxb.), a traditionally used North-Eastern Indian vegetable. Biomed Pharmacol J 2014;7:635-44.

40. Junejo JA, Zaman K, Rudrapal M, Mondal M, Singh KD, Verma VK. Preliminary phytochemical and physicochemical evaluation of Carallia brachiata (Lour.) Merr. leaves. J App Pharm Sci 2014;4:123-7.

41. Vemuri SK, Banal RR, Subbaiah GP, Srivastava SK, Reddy AG, Malarvili T. Anti-cancer potential of a mix of natural extracts of turmeric, ginger and garlic: A cellbased study. Egypt J Basic Appl Sci 2017;4:332-44.

42. World Health Organization. Cancer Fact Sheet. Geneva: World Health Organization; 2017. Available from: http:// www.who.int/mediacentre/factsheets/fs297/en. [Last accessed on 2017 Jul 22].

43. World Health Organization. Latest World Cancer Statistics. Geneva: World Health Organization; 2012. Available from: https://www.iarc.fr/en/media-centre/pr/2013/pdfs/ pr223_E.pdf. [Last accessed on 2012 Aug 12].

44. Yadav RN, Agarwala M. Phytochemical analysis of some medicinal plants. J Phytol 2011;3:14.

Source of Support: Nil. Conflicts of Interest: None declared. 